\title{
From One Master of Horror to Another: Tracing Poe's Influence in Stephen King's The Shining
}

\section{Maroš Buday}

This article deals with the work of two of the most prominent horror fiction writers in American history, namely Edgar Allan Poe and Stephen King. The focus of this study is put on the comparative approach while tracing the influence of Poe's several chosen narratives in King's novel called The Shining (1977). The chosen approach has uncovered that King's novel embodies numerous characteristics, tendencies, and other signs of inspiration by Poe's narratives. The Shining encompasses Poe's tales such as "The Masque of the Red Death", "The Fall of the House of Usher", and "The Black Cat" which are shown to be pivotal aspects of King's novel. The analysis has shown that the aforementioned King's novel exhibits Shakespearean elements intertwined with Poe's "Masque of the Red Death", the Overlook Hotel to be a composite consisting of various Poesque references, and that The Shining's protagonist is a reflection of autobiographical references to specific aspects of the lives of Poe and King themselves.

\section{Keywords}

Edgar Allan Poe; Stephen King; The Shining; Shakespearean elements; autobiographical elements

\section{Introduction}

Horror fiction has always been a vital part of literature. It was condemned in the past as much as it is praised in the present, paradoxically, for the same reason. It has depicted twisted images of violence, anger, dark corridors of the human psyche but also morality and society in a way which stands in opposition to conventional norms. This article attempts to deconstruct one of Stephen King's most popular novels called The Shining (1977) in an intertextual and thematic context. This novel, through the course of the article, is being compared with several of the most prominent short stories written by Edgar 
Allan Poe, namely "The Masque of the Red Death", "The Fall of the House of Usher", and "The Black Cat".

Stephen King's writing is rarely addressed in an academic manner which is the result of his fiction being marginalized to the fringes of literary discourse. This is due to mostly negative but superficial criticism which labels his work as sub-standard when it comes to academic focus in literary studies. However, it can be argued that King's fictional corpus features a vast number of various novels and short stories which often contain political, economic, social or philosophical issues which call his position in literature into question, and at the same time, justify the article's purpose. The aim of this article is to demystify the nature of his connection to the chosen narratives of Edgar Allan Poe via the exploration of thematic similarities which are encompassed in the aforementioned works of fiction.

\section{Finding Shakespeare where None Would Expect It}

The Shining is the best source of endless examples of inspiration by Edgar Allan Poe there is to find among King's fictional universe. This novel was modelled upon several of the greatest of Poe's narratives, namely "The Fall of the House of Usher", "The Black Cat", and "The Masque of the Red Death". The interesting thing about King's novel is that this piece is King's original story with many elements and specific references to Poe, his life, elements, and the themes he used in these three respective tales.

The Shining tells the story of Jack Torrance, a middle aged writer with a previous alcohol abuse problem, who takes a position as a caretaker at the Overlook Hotel which is a structure completely isolated from the rest of civilization, and is closed for the winter during which Jack, his wife and son are supposed to stay there. From the moment Jack and his family get to the Overlook, he is immediately but slowly haunted by the "residents" of the hotel. The hotel is riddled with many ghosts but what is important is that the corruptive force of these spectral manifestations is limited, as it is learned later in the story, to the caretakers of the hotel. Jack Torrance's past is full of disappointments, self-pity and alcoholism; and people who have struggled with these kinds of problems tend to lapse back to their old habits because they do not have their demons completely under control. This is exactly the case of Jack, who becomes immediately susceptible to the malevolent forces 
of the Overlook which slowly and gradually take hold of his psyche and twist it to their own crooked ways. Jack slowly returns to his vices under the subtle influence of the Overlook's spectres and subsequently turns on his family with murderous intentions, an act that ultimately leads to his demise.

This novel bears several subtle and explicit allusions to Poe's "Masque of the Red Death". The characters of Jack Torrance and Prince Prospero have numerous things in common. Firstly, they are both modelled upon Shakespearean dramas. Poe's Prospero is a character taken over from Shakespeare's late comedy The Tempest, but Poe's protagonist shares no similarity with the Duke of Milan, apart from his severe isolation. Poe's character is an irrational hedonist, as he remains oblivious to the fact that his subjects are suffering from a fatal disease. His oblivious stance to this fact is realized when Prospero calls all of the nobles for a masquerade ball which lasts for six months while his dominion remains decimated by the plague.

The Shining, as King acknowledges in a collection of interviews entitled Bare Bones: Conversations on Terror with Stephen King (1988), was originally structured "in the form of a five-act Shakespearean tragedy" (14). Jack Torrance, apart from Prospero, bears a striking resemblance to Shakespearean tragic heroes. In the same way as Shakespeare's, King's universe operates, at least partly, on the concept of free will. King's characters seem to be free to choose their destiny which is not predetermined by fate. And so, Jack Torrance, same as Shakespeare's protagonists, free-willingly morally descends way beyond the point of no return because of his own foolish choices and susceptibility.

The similarities continue to arise in the form of Jack's isolation from society in the Overlook, but more importantly, by his impending doom. Jack is basically a classic Romantic anti-hero and this is quite similar to Poe's protagonists, even Prospero in "The Masque of the Red Death". Both Jack's and Prospero's choices are unfortunate but they are choices of their own and they gradually lead to the ultimate destruction of both protagonists. Even the climax of The Shining is classically Shakespearean. Jack's wife and child abandon him in his chaotic and corrupt state of mind, thus allowing Jack to descend further into madness, which is being already fueled by the ghosts of the Overlook. King describes his protagonist as an abomination; his face "lathered in blood, the single eye, tiny and piggish and glittering", his articulation is reduced to incoherent howls. In short, he is transforming into "a strange, shifting composite" (429), resembling the spectres of the Overlook Hotel. 


\section{The Overlook Hotel - A Poesque Composite}

The Overlook is presented as the ultimate embodiment of a haunted house. With its infamous history of

drugs, vice, robbery, murder [...] and they [the transgressors] had all been here, right above him, in those empty rooms [...] Every hotel has its ghost? The Overlook had a whole coven of them. First suicide, then the Mafia, what next? (163)

Apart from the many ghosts inhabiting the hotel, its structure and interior are remarkably similar to the abbey in which Prospero is hosting his masquerade ball. Prospero's abbey is an enormous structure with "the apartments [...] so irregularly disposed that the vision embraced but little more than one at a time. There [is] a sharp turn at every twenty or thirty yards, and at each turn a novel effect" (Poe "The Masque", 758). The hotel in King's The Shining is an exceptional replica of the abbey embodied in Poe's short story. Both buildings are enormous and void of symmetry, and both embody numerous twisted corridors and dark hallways which hold a uniquely claustrophobic atmosphere. King's portrayal of the Overlook Hotel is very skilfully mirrored with Prospero's abbey, however, King manages to push Poe's climate of the structure a bit farther. Not only is the Overlook, as is Prospero's abbey, an enormous, asymmetrical building; it is also emptied of human presence which definitely cannot be said about Prospero's home. The Overlook completely isolates Jack from the rest of civilization, leaving him stranded with his family which inevitably leads to him experiencing symptoms similar to cabin fever. He is lead to insanity, not only by being in a position of a social outcast, but also by the fact that he remains indoors at all times, even when his family spend time outside.

However, the Overlook Hotel is, for the most part, modelled upon another of Poe's great mansions, which is the Usher house. This instance represents one of several examples of King's adoption of Poe's technique of mimicking the state of a character's psyche upon the environment.

In many of Poe's short stories, there is a distinct tendency encompassed within them where Poe parallels the state of a character's psyche with the environment of a particular story. In his narratives, Poe has a way of utterly confusing the reader by the means of creating the environment akin to none other. Poe makes us wonder whether the setting of a story is real, or if it 
is a projection of the state of mind of the character, much like it may be speculated on account of "The Fall of the House of Usher", where the nameless protagonist of the story describes the house as a melancholic vision:

Its [the house's] principle feature seemed to be that of an excessive antiquity. The discoloration of ages had been great. Minute fungi overspread the whole exterior, hanging from a fine tangled web-work from the eaves. Yet all this was apart from any extraordinary dilapidation. No portion of the masonry had fallen; and there appeared to be a wild inconsistency between its still perfect adaptation of parts, and the crumbling condition of the individual stones. (53)

The polarity of thought of the story's protagonist is more than apparent from this excerpt. The logical dissimilarities in the vision of the mansion's crumbling, yet perfectly intact exterior point to some external forces holding the foundation of this structure intact.

As can be found later in the story, the owner of the house, Roderick Usher, is in a very similar state of mind as is the house and the worse his mental state gets, the worse and bleaker does the house itself appear. Near the end of the story, after Usher's sister, Madeline, suddenly reappears, she takes revenge on her brother who dies in a state of complete madness. Madeline's recurrence, though the story does not offer a suitable explanation for it, directly points to some kind of a transgression towards her on account of Roderick Usher which is expanded to the narrator of the whole story as well, because of his agreement to help entomb Madeline's (live or dead) body. As Usher dies, the house dies with him and collapses. The external forces holding the house together are revealed to be none other than the sole power of Usher's mind whose state is projected at the slowly, but surely decaying structure.

King's novel, however, though it adopts Poe's technique of projecting the state of the character's mind onto the environment of the story, appears to be vice versa. It is so because Jack Torrance is not the only caretaker who has fallen to the evil seduction of the Overlook Hotel. This means that Jack's crumbling psyche is not the cause for the Overlook's supernatural manifestations, as it is in "The Fall of the House of Usher", it is rather the other way around. Jack's psyche strongly resembles the twistedness and darkness interiorized in the hotel itself as well as in its spirits. Roderick Usher's demise in his house and the sole destruction, or rather self-destruction, of Jack Torrance seem to be the work of events and decisions which both protagonists willingly made in the 
course of both respective tales. In Jack's case however, though shaped by his decision to start drinking again, and as a result, allowing his aggressiveness to take hold of him, he seems to be only partly at fault for his actions. Jack's vices appear only as the fuel which is conclusively lit aflame by the corruptive presence of the Overlook's spectres. It is merely by chance that Jack's psyche sufficiently syncs up with the overall ambiance of the spirits which embody the hotel itself. Ultimately, as Magistrale put it in his Landscape of Fear: Stephen King's American Gothic (1988), "Torrance can no more depart from the Overlook than Usher could abandon the crumbling mansion that becomes his tomb" (17). Jack's and Usher's deaths are the result of sin and murder which lead both protagonists astray.

On the other hand, there is a different way to view the infamous Overlook Hotel. This structure may not be a structure at all, but it seems to be a dual, Platonic construct. The first part of this composite is the hotel itself consisting of its foundation, hallways, suites, etc. The second component, however, are the spectres which inhabit the Overlook Hotel. These entities possess a degree of reality which resembles a soul, as they are bound to the building itself. Therefore, it could be argued that the Overlook Hotel is a living entity not much different from a human being, as it too has a body in the form of the building and a mind which is represented by the spirits of the Overlook which are, to a greater extent, independent of the structure of the hotel itself. In this sense, the Overlook may be considered as one of the characters of The Shining in the same manner as Jack Torrance, his son, Danny, or his wife, Wendy, are a part of this particular Kingian universe of this novel.

When this observation is taken into account, Stephen King upholds Poe's aforementioned technique to the letter. The Overlook represents the ultimate main character as well as a Romanticist, Gothic anti-hero. In this sense, it can be argued that the Overlook's spectres which constitute its mind, project their twisted desires and characteristics onto the visual presentation of the structure of the hotel itself as well as the rest of its grounds. This assumption completely remakes the notion of The Shining's original impression of Jack Torrance and his family to be at the heart of the story.

\section{Edgar Allan Poe - That Literary Hack!}

King's The Shining is a novel which portrays and shows the influence of Poe on Stephen King at its best. Though it may be speculated that the Overlook is 
not based on the Usher house and Prospero's abbey, or that Poe's protagonist of "The Masque of the Red Death" and King's Jack Torrance are not modelled upon the great Shakespearean plays, The Shining embodies an indisputable proof of an inspiration by one of Poe's narratives.

At a certain point in the story, Jack finds an old invitation to a masquerade ball, and as he reads it, the response of Jack' s mind appears to be more than baffling:

(The Red Death held sway over all!)

He frowned. What left field had that come out of? That was Poe, the Great American Hack. And surely the Overlook - this shining, glowing Overlook on the invitation he held in his hands-was the farthest cry from E.A. Poe imaginable. (157)

The first line is a paraphrase of Poe's last line in "The Masque of the Red Death". The explicit and deliberate mentioning of "Red Death" might be a shriek for help from Jack's own subconscious, warning him about the dangers of handing himself over to the preternatural powers of the Overlook Hotel. Jack's subconscious is aware of these dangers and recognizes them, but Jack's own already haunted and corrupted psyche is reluctant to perceive the threat and therefore rationalizes the warning which is presented in the form of Poe's own paraphrased line - "The Red Death held sway over all!" The ignorance of the suffering of Prospero's dominion leads to his demise, same as the ignorance of Jack's inner voice, not to mention his own family, ultimately leads to his death. Jack's reaction to the warning is masterfully constructed by King, as him frowning and calling Poe a hack is the reaction of his haunted psyche, the brief moment where his consciousness overrules his subconscious mind.

King presents Jack as a struggling writer void of his ability to create original pieces of literature. Jack's writer's block is pronounced and accentuated throughout the whole story. Because Jack is an American writer, the chances of him not knowing Poe's work and the importance of his place in the literary tradition are astronomical. Poe is one of the best known writers of all time for his innovative techniques in fiction as well as poetry, and Jack's proclamation of Poe being a hack is a great denouncement of one of the giants of American literature. What this act evokes in the reader, is Jack's anger and resentment, perhaps even jealousy with respect to Poe, at the fact that he is unable to write anything.

In addition to Jack's psyche being haunted by his own past demons and 
the Overlook's evil forces, it becomes haunted by Poe himself and his own maddened mind, which makes things for Jack, not to mention his family, a lot worse. Simply put, Jack gives up, and at this point in the story fully hands himself to the spectres of the Overlook.

Jack and Prospero share much in common because they are both oblivious to the suffering of the people who are looking up to them and expecting salvation from them: Prospero's subjects in a form of a cure for the illness and Jack's wife and child in the form of deserved recognition and protection from the supernatural forces haunting the Overlook Hotel. Neither Jack nor Prospero hold up their end of the bargain and thus are severely punished for their sins. Another similarity between the two is that they are both "consumed with their own worldly success and social status" (Magistrale "Teaching Poe and King", 142). Jack enjoys the masquerade ball full of the spectres of the Overlook as it materializes in front of him in the same manner as Prospero enjoys his ball.

Magistrale addresses this seemingly odd gesture of King calling Poe a hack as King's reaction to his literary critics:

I hear King himself here repeating the diminutive criticism often leveled at him by Harold Bloom and others, that he is a literary hack. And add Jack Torrance to this mix, a man who wants desperately to be taken seriously as a writer. Lastly, Jack has been busy thinking lofty thoughts about the Overlook - its place as a potential book, at the matrix of post-World-WarII America. The reference to Poe, it seems to me, is slightly out of place in these lofty thoughts. But Poe is also exactly what is at the heart of this place, more at the truth of the Overlook than any of the inflated dreamy images floating in Torrance's head. (personal consultation with Anthony Magistrale)

Indeed, King has been struggling with the marginalizing of his fiction by literary critics, and Magistrale may be right about this biographical element within King's novel. This fact becomes more germane as the analysis of the parallel of Poe's and King's fictional corpora and their real lives as authors and human beings are taken into account. 


\section{Addressing Alcoholism: The Bane of Human Existence}

King's literary corpus embodies numerous examples of the destruction of familial values. On the other hand, Poe's stories rarely encompass such themes, but there is a connection between another one of his stories and The Shining.

"The Black Cat" is one of the best examples of a crumbling familial relation and its protagonist and Jack Torrance are quite alike. "The Black Cat" is a story about a man haunted by his sin of killing his wife's favourite pet for no apparent reason. But most of Poe's stories are written in a rational manner, and things which occur in them are usually logically structured and argued. It seems that the protagonist in "The Black Cat" rationalizes his reason with irrational arguments which he presets to himself. But it is very possible that the anger is simply misplaced and transferred to the cat, and at the end of the story, it is aimed towards the true object of concern - the protagonist's wife.

"The Black Cat" could be interpreted as a story of a slowly crumbling familial relation, escalated to a point where an act of murder is committed. This could also explain the reason why the protagonist is so calm when the police enter and search his house. Because the character does not reflect the behaviour of a psychopath, not initially at least, and his anger is, at first, aimed at his wife's favourite cat, it is very possible that Poe's character acts out of hate he carries and transfers from his wife to his cat. This resembles Jack Torrance's own state of mind in The Shining. Jack is an unsuccessful writer, plagued by substance abuse and self-pity, which ultimately results in a misplacement of anger. But its transference is from the hate which he carries for himself onto his family, which is further fueled and driven by the spirits of the Overlook.

Both Jack and the protagonist of Poe's "The Black Cat" are literary characters who are troubled by substance abuse, and are hostile towards their surroundings. Alcohol plays a vital role in both characters' mental decline. However, there may be more to this than meets the eye. Alcoholism is a recurring theme in both authors' works and is assigned a great deal of attention. As Magistrale suggested, King's novel The Shining embodies an autobiographical element, however, it is not just the case of Torrance's/King's literary misfortunes. King's novel is a "shining" example of how alcohol abuse can ruin a man's life.

The characters of Jack Torrance as well as Poe's protagonist of "The Black Cat" are modelled on the biographies of two of the greatest horror fiction 
writers. In many respects, King's and Poe's life stories are very similar. Poverty, alcoholism and gambling were the demons which afflicted both of the respective authors. In the case of The Shining, King has put much of himself into the novel's protagonist. Jack Torrance's reason for departing from Stovington where he taught English, thus being forced to take a job as the caretaker of the Overlook, was that he had hit a student because of his alcoholism and volatile temper. After college, King himself also taught English in Maine, but unlike Jack who had writer's block, "King was unable to write because his job took all of his time" (Dyson 16). However, both Torrance and King failed to produce what they believed was their greatest passion.

The character of Jack Torrance thus seems to serve as a reflection, and a reminder to King, of what would become of his life and personality if it were not for his literary success as a writer. As he acknowledges in Bare Bones:

I'd wander around the crummy little living room of our trailer at three o'clock on a cold winter's morning with my teething nine-year-old son Joe slung over my shoulder [...] and I'd try to figure out how and why I'd ever committed myself to that particular lunatic asylum [...] and I'd say to myself, ' $[. .$.$] face it; you're going to be teaching high school kids for the$ rest of your life.' I don't know what would've happened to my marriage and my sanity if it hadn't been for the totally unexpected news [the publication of King's first major literary success - Carrie]. (31-32)

Jack Torrance is basically a representation - a symbol, a foreshadowing of King's parallel self which has never come into being, however his presence in King's novel, the presentation of his vices through alcoholism and other similarities with King's life, are symptomatic of the looming, inescapable presence of his life that might have been: "I could see myself 30 years on, wearing the same shabby tweed coats with patches on the elbows, potbelly rolling over my Gap khakis from too much beer [...] and in my desk drawer, six of seven unfinished manuscripts which I would take out and tinker with from time to time, usually when drunk" (Dyson 17). Indeed, King has never kept his previous problem with alcohol addiction to himself; on the contrary, alcohol abuse makes up a vital part of his literary corpus, and has been frequently and extensively analyzed from his point of view. King's remorse for his life before he became successful is best expressed in Bare Bones: "I wish I could say today that I bravely shook my fist in the face of adversity and carried on undaunted, but I can't. I copped out to self-pity and anxiety, and started 
drinking far too much and frittering money away on poker and bumper pool" (30-31). Fortunately, at least Stephen King pulled through the tough times and managed to create a vast literary universe worth studying.

The parallel between Poe and King deepens when these facts about King's life are taken into account. Jack Torrance and The Shining itself are both very complicated composites. On the one hand, the character of Jack embodies attributes of King's own past life, and on the other hand, at the heart of The Shining stands none other than Poe himself. This suggests that Jack Torrance really represents King's and Poe's haunted pasts, but unlike King, Jack and Poe eventually died because of their vices.

\section{Conclusion}

This analysis of Stephen King's novel The Shining has been conducted in terms of his possible inspiration by one of the greatest American writers, Edgar Allan Poe. King's novel has shown itself to be deeply connected with the short stories of Edgar Allan Poe which have been chosen as the most suitable elements in this kind of inquiry. The Shining bears striking similarities to Poe's short stories "The Masque of the Red Death", "The Fall of the House of Usher", and "The Black Cat" in several aspects. First of all, The Shining and "The Masque of the Red Death" both encompass Shakespearean elements embedded within their structure. Secondly, King's adoption of Poe's own technique of paralleling the state of the character's mind to the environment while actively changing it, has been addressed via presenting the notion of the origin for King's creation of the Overlook Hotel which is modelled upon Prince Prospero's Abbey from Poe's "Masque of the Red Death" and the Usher house from "The Fall of the House of Usher". Furthermore, the analysis has uncovered a bipolar essence of the Overlook Hotel which allows it to acquire the status of a literary character which has the potential to change the interpretation of the whole novel. Lastly, this article analyzes an explicit allusion to Edgar Allan Poe himself which leads to the exploration exposing the inclusion of biographical elements of both King and Poe within the character of Jack Torrance in The Shining.

Although there are many similarities shared between the two aforementioned authors, "the jump from Poe to King is really more of a skip because for Stephen King, Poe has always served as a kind of refrain that haunts the edges of his stories, giving it resonance if you recognize the Poe allusion, but there 
only to the point where the narrative is deepened, rather than complicated $[\ldots]$ by the Poe inclusion" (personal consultation with Anthony Magistrale). Poe thus serves as a looming reference within King's fictional corpus which gives his work a higher degree of importance. Stephen King's fiction is a body of work truly worth studying within the realm of high-culture literature, and Stephen King himself is a writer whose work may be of great interest if one is able to pierce the veil of the horrific elements embedded within his work in order to explore what lies beyond.

\section{Works Cited}

Dyson, Cindy. "Biography of Stephen King." Bloom's Bio-Critiques: Stephen King. Ed. Harold Bloom. Philadelphia: Chelsea House Publishers, 2002. 3-48. Print.

King, Stephen. The Shining. London: Hodder and Stoughton, 2007. Print. Magistrale, Anthony. Landscape of Fear: Stephen King's American Gothic. Madison: Popular Press, 1988. Print.

---. "Teaching Poe and King in the American Literature Classroom." Approaches to Teaching: Poe's Prose and Poetry. Ed. Anthony Magistrale. New York: Modern Language Association of America, 2008. 139-145. Print.

Personal consultation via e-mail with Anthony Magistrale Ph.D. February 3rd and April 4th, 2011.

Poe, Edgar Allan. "The Masque of the Red Death." Tales of Mystery and Imagination. Ware: Wordsworth Editions Limited, 2000. 757-766. Print.

--. "The Fall of the House of Usher." Tales of Mystery and Imagination. Ware: Wordsworth Editions Limited, 2000. 51-66. Print.

--.. "The Black Cat." Tales of Mystery and Imagination. Ware: Wordsworth Editions Limited, 2000. 235-243. Print.

Underwood, Tim et al. Bare Bones: Conversations on Terror with Stephen King. New York: Warner Books, 1988. Print.

MAROŠ BUDAY is a Ph.D. candidate at the University of Prešov, Institute of British and American Studies, Slovakia. He graduated in Teacher Training in English Language and Literature, and Philosophy at the same university. His current field of research deals with postmodernist literature as well as the relation between cosmology in physics and the nature of literary discourse. $\mathrm{He}$ 
FROM ONE MASTER OF HORROR TO ANOTHER

is currently writing his dissertation thesis entitled The Concept of the Multiverse and Postmodernist Literature.

maros.buday@gmail.com 